\title{
Electrospun Polyethersulfone Nanofibers: A Novel Matrix for Alpha-Amylase Immobilization
}

\author{
Marzieh Ghollasi ${ }^{*}$ \\ ${ }^{1}$ Department of Cell and Molecular Biology, Faculty of Biological Sciences, Kharazmi University, Tehran, Iran \\ Corresponding Author: Marzieh Ghollasi, Department of Cell and Molecular Biology, Faculty of Biological Sciences, Kharazmi \\ University, Tehran, Iran. Tel: +98-6633120097, Email: ghollasi@khu.ac.ir
}

Received December 27, 2017; Revised February 25, 2018; Accepted March 2, 2018; Online Published March 30, 2018

\begin{abstract}
Introduction: Amylases are used in various industries, mainly, starch processing that hydrolyze polysaccharides. Insoluble and solid supports are noteworthy in immobilization of enzymes for industry because of increasing enzyme stability. In this study, immobilization of alpha amylase in electrospun polyethersulfone (PES) nanofibers was studied.

Materials and Methods: Covalent immobilization of the enzyme was done through the carboxyl groups made by oxygen plasma treatment and 1-Ethyl-3-(3-dimethylaminopropyl) carbodiimide (EDC) as a carboxyl group activator agent. Attenuated total reflectance Fourier transform infrared (ATR-FTIR) and contact angle analysis proved enzyme immobilization. The optimum conditions determined and the catalytic parameters of immobilized enzyme were calculated.

Results: The results of this investigation showed that the optimum $\mathrm{pH}$ of immobilized enzyme was displaced toward acidic region by 1 unit. Comparison of the optimum temperature for immobilized and free amylase revealed $10^{\circ} \mathrm{C}$ increasing for the immobilized enzyme. Furthermore, the kinetic parameters, $V_{\max }$ and $K_{m}$ for the immobilized enzyme were the same and higher than those of free ones, respectively. Storage stability of the immobilized amylase was obviously improved.

Conclusions: The results illustrated that nanofibrous supported alpha amylase is a new and suitable matrix for industrial applications. Keywords: Polyethersulfone (PES), Electrospinning, Nanofibers, Immobilization, Alpha Amylase

Citation: Ghollasi M. Electrospun polyethersulfone nanofibers: a novel matrix for alpha-amylase immobilization. J Appl Biotechnol Rep. 2018;5(1):19-25. doi:10.29252/jabr.01.01.04.
\end{abstract}

\section{Introduction}

Amylases belong to glycosyl hydrolase family 13 and specifically break O-glycoside bonds in starch. ${ }^{1}$ These enzymes with approximately $25 \%$ share of the enzyme market have been employed in some industrial processes such as food, textile, paper and medical industries. ${ }^{2}$ The immobilization of enzymes on various supports can increase stability, easy resumption and sequential use of a single batch of enzyme which will finally save the enzyme and decreases the extra costs. ${ }^{3,4}$ This process can be done by a chemical method like electrostatic or covalent bond between the enzyme and the support, or a physical way, such as adsorption or entrapment of the enzyme. ${ }^{5}$ There are different reports on the immobilization of alpha -amylase on different carriers by different methods. Several materials for amylase immobilization such as sodium alginate, agar, ceramic, wool, glass wool, glass, polystyrene, magnetic nanoparticles, cation and anion exchange resins, gelatin, chitosan, cellulose, starch, sepharose, silica, amberlite and acrylic carriers have been used. ${ }^{6-17}$ Recently, researchers have been interested in cross linking of enzymes to electrospun nanofibers because of increased surface area to volume ratio and porosity. ${ }^{18}$ Till now, some nanofibers such as poly(vinyl alcohol)/poly(acrylic acid) (PVA/PAA) nanofibers and poly(glycidyl methacrylate) grafted electrospun fibers have been used for amylase immobilization. ${ }^{19,20}$ In the present study, a-amylase was immobilized onto polyethersulfone (PES) nanofibers, which could be a proper candidate for being used in the industry. For this purpose, PES nanofibers were constructed by electrospinning method. Activation of acid groups produced by plasma treatment creates considerable binding sites for the enzyme. Alpha amylase immobilization was done covalently by EDC as a reagent and eventually the biochemical characteristics of immobilized enzyme versus free enzyme were examined.

\section{Materials and Methods}

Materials

Polyethersulfone (molecular weight of $58000 \mathrm{Da}$ ) was purchased from BASF (Germany). Chloroform (99.6\% purity) and $\mathrm{N}, \mathrm{N}$-dimethylformamide (DMF) (99.5\% purity) were received from Merck (Germany). 2-(Nmorpholino) ethanesulfonic acid (MES), 1-ethyl-3-(3dimethylaminopropyl) carbodiimide hydrochloride (EDC), a-Amylase (1,4-a-D-glucan-glucanohydrolase; EC 3.2.1.1

Copyright (C) 2018 The Author(s). This is an open-access article distributed under the terms of the Creative Commons Attribution License (http:// creativecommons.org/licenses/by/4.0), which permits unrestricted use, distribution, and reproduction in any medium, provided the original work is properly cited. 
from Bacillus subtilis; extra pure $380 \mathrm{U} \mathrm{mg}^{-1}$ ), starch, maltose, 3,5-dinitrosalicylic acid (DNS), sodium potassium tartrate and $\mathrm{NaOH}$ pellets were purchased from Sigma (St. Louis, MO, USA).

Preparation of Polyethersulfone Nanofibers

PES nanofibers $(24 \% \mathrm{~W})$ was synthesized by electrospinning technique. In this method, PES polymer solution was collected on a rotary collector from a metallic needle by a flow rate of 1 $\mathrm{mL} / \mathrm{h}$. The distance of rotating cylindrical drum from needle was $15 \mathrm{~cm}$.

\section{Analysis of Nanofibers}

The photographs of the nanofibers were taken by a scanning electron microscopy (SEM) (KYKY-EM3200, Japan) and gold coated samples were imaged under high vacuum.

\section{Surface Modifications}

The plasma technique with a microwave plasma generator of $40 \mathrm{kHz}$ frequency and a cylindrical quartz reactor (Diener Electronics, Germany) was used for increasing the hydrophilicity of the nanofibers. Oxygen plasma treatment was carried out under 0.4 mbar pressure and $45 \mathrm{~W}$ power for 5 minutes.

\section{Contact Angle Measurements}

The hydrophilicity of the electrospun PES nanofibers was evaluated by contact angle technique. The surface wetting characteristics were tested by a drop-shape analysis device (OCA 15plus, Data physics GmbH, Filderstadt, Germany). Deionized water droplets were put onto the matrix surface by a syringe at room temperature and the droplet shape was captured with a CCD camera after 10 seconds. The angle between the droplet base line and the tangent of the water/ air boundary was used for contact angle calculation. Five measured contact angles were used for statistical analysis.

\section{Activation With Carbodiimide}

Fabricated and treated fibers were cut as disks and placed in a 24-well culture plate. After washing with MES buffer (50 mM; pH 5), EDC solution (60 mM in MES buffer) was added to nanofibers disks, kept in a shaking water bath for 1 hour at $25^{\circ} \mathrm{C}$. The activated nanofibers were washed 3 times with phosphate buffer (50 mM; pH 5).

\section{Enzyme Immobilization}

The enzyme solution ( $2 \mathrm{mg}$ enzyme/mL PBS) was added to activated nanofibers and the immobilization reaction was done at $4^{\circ} \mathrm{C}$ for 12 hours. For omitting the unbound enzymes, the surface of matrix was washed three times with PBS (50 $\mathrm{mM} ; \mathrm{pH}$ 5). The immobilized enzymes were used freshly. The scheme of activation and enzyme immobilization on nanofibers are shown in Figure 1.

\section{ATR-FTIR Analysis}

In order to investigate the chemical changes of nanofibers surface, Fourier transform infrared (FTIR) spectrum was recorded on Equinox 55 (Bruker Optics, Germany) FTIR spectrometer with deuterated triglycine sulfate (DTGS) detector and a diamond attenuated total reflectance (ATR) attachment.

\section{Immobilization Yield}

After the enzyme immobilization process, UV absorbance of the supernatant and the wash solutions were measured at $280 \mathrm{~nm}$ by using a UV-spectrophotometer (Shimadzu, Model 1201). The enzyme calibration curve was prepared at $280 \mathrm{~nm}$ and used for calculation of the amount of unbound enzymes. The immobilization yield of $\alpha$-amylase (E) was evaluated according to Eq. (1):

$E \%=\frac{C_{1}-C_{2}}{C_{1}} \times 100$

Where $\mathrm{C}_{1}$ and $\mathrm{C}_{2}$ are the concentrations of $\alpha$ - amylase used in the immobilization reaction and the sum of unbound enzymes in the supernatant and washes after immobilization, respectively.

Activity Assays of immobilized and Free $\alpha$-Amylase Enzyme activities of free and immobilized -amylase were evaluated by Bernfeld method. ${ }^{21}$ The activity of amylase was assessed by quantifying the amount of maltose released from starch. Miller procedure was used to quantify the maltose..$^{22}$ Twenty microliters of the free or immobilized enzyme and 80 $\mu \mathrm{L}$ of $1 \%$ starch solution $(\mathrm{w} / \mathrm{v})$, both prepared in phosphate buffer ( $\mathrm{pH}$ ), were mixed in test tube and then incubated at

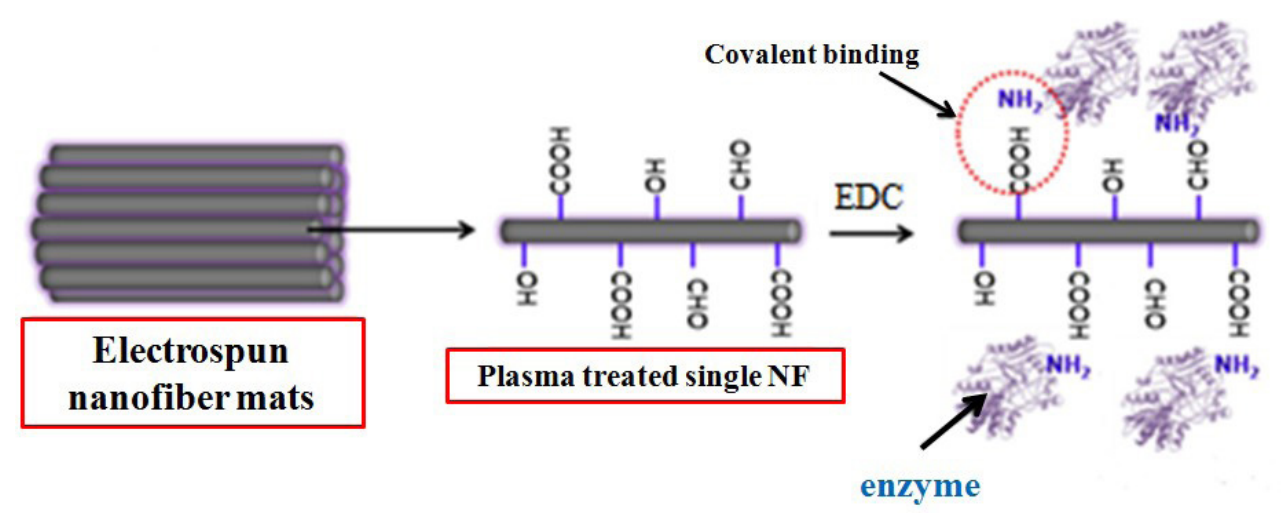

Figure 1. The Scheme for Activation of Electrospun Nanofibers and Enzyme Binding. 
$40^{\circ} \mathrm{C}$ for 30 minutes. After that $100 \mu \mathrm{L}$ of 3,5-dinitrosalicylic acid (DNS) was added as the terminator of the reaction then was boiled at $100^{\circ} \mathrm{C}$ for 5 minutes. The absorbance at 540 $\mathrm{nm}$ was used for determining the released maltose in the reaction volume. One unit of enzyme activity $(U)$ was defined as the amount of the enzyme releasing $1 \mu \mathrm{mol}$ of reducing sugars per minute under the assay conditions. All mentioned measurement experiments were done at least three times and the percent of relative standard deviations were less than $5.0 \%$.

Effect of Temperature and $\mathrm{pH}$ on the Activity of Amylase The temperature and $\mathrm{pH}$ range of $30-60^{\circ} \mathrm{C}$ and 4 to 8 was used to determine optimum temperature and $\mathrm{pH}$ for both forms of amylases. The relative activity (\%) was calculated by considering the activity of every sample into the maximum one $(100 \%)$.

Assessment of Storage Stability and Reusability of Amylase The storage stability of the free and immobilized amylase was estimated by storing the enzymes at $4^{\circ} \mathrm{C}$ for 9 days and the remaining activities were determined every day ( 24 hours). Also for determining the reusability of the immobilized amylase, the remaining activity of the enzyme was tested after reacting for 30 minutes with $1 \%$ soluble starch. The $\mathrm{pH}$ and temperature of the reaction medium were optimum. After each usage, the nanofiber disk was washed three times by PBS (50 mM; pH 6) and then another fresh reaction medium was used. The activity was measured as described before. The initial activity of the enzyme was assigned as $100 \%$.

Determination of Kinetic Parameters of Immobilized and Free Amylase

The reaction progress curve assay was prepared by different concentrations of starch. The kinetic parameters of both forms of studied enzyme were determined from the LineweaverBurke plots.

\section{Ethical Considerations}

This study does not involve the use of human subject or animal experiments and so does not require an approval from the ethical committee.

\section{Results}

Properties of Nanofibers

SEM micrograph of PES nanofibers demonstrated the formation of ordered nanofibers by electrospinning method (Figure 2). Fabricated electrospun nanofibers had a high porosity construction and bead-free surfaces with a $250 \pm 10$ $\mu \mathrm{m}$ electrospun matrix thickness as well as $210 \pm 40 \mathrm{~nm}$ average diameter of fibers.

\section{Contact Angle Analysis}

The contact angle of nanofibers after plasma treatment decreases from 130 to 0 degree (Figure 3).

Enzyme Immobilization on Nanofibers

Optimization of Immobilization Conditions

In order to optimize the immobilization of the enzyme on

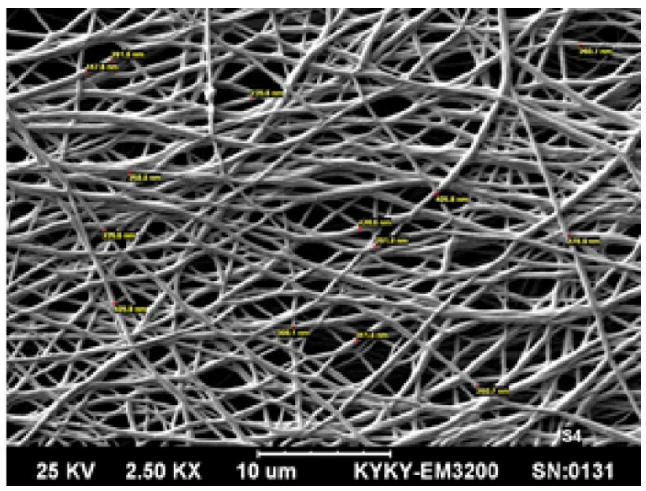

Figure 2. SEM of PES Nanofibers. The porous structure of PES nanofibrous matrix is clear. The diameter of nanofibers is determined $210 \pm 40 \mathrm{~nm}$.

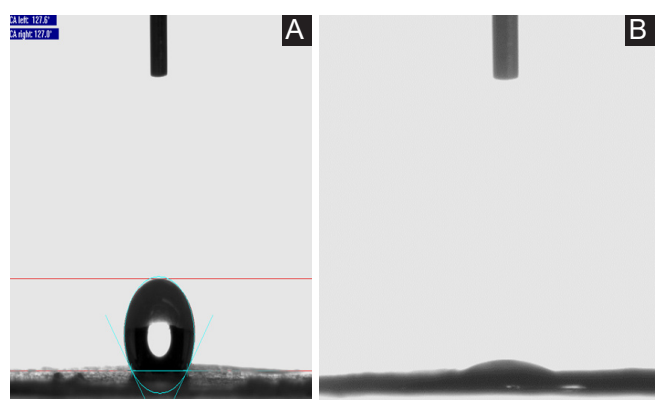

Figure 3. The Contact Angle Determined Before (A) and After (B) Oxygen Plasma Treatment of PES Matrix.

treated nanofibers various conditions were tried and the activities of the immobilized amylase were assessed. The given results are shown in Table 1 . These experiments were done at least 3 times and the relative standard deviation values were less than $5 \%$. The immobilization yield of $\alpha$-amylase was found to be $58.6 \%$.

\section{ATR-FTIR Spectra}

In order to examine the immobilization of alpha amylase on the plasma treated nanofiber support (under the optimum conditions), the ATR- FTIR spectrum was taken (Figure 4). The characteristic peaks at 1654 and $2800-3500 \mathrm{~cm}^{-1}$ region were appeared.

\section{Parameters Affecting Enzyme Activity}

The effects of variable $\mathrm{pH}$, temperature and storage time were determined by calculation of the activities of free and immobilized enzyme. The activities of the enzymes were calculated using the maltose calibration curve in each experiment.

Table 1. Optimal Conditions of $\alpha$-Amylase Immobilization on Polyethersulfone Support

\begin{tabular}{lcc}
\hline Condition & Varied Amounts & Optimum Condition \\
\hline$[E D C](\mathrm{mM})$ & $20,40,60,80,100$ & 60 \\
$\mathrm{pH}$ & $4.6,5,5.4,5.8,6.2$ & 5 \\
{$[$ Enzyme] $(\mathrm{mg} / \mathrm{mL})$} & $0.1,0.5,1,2,5$ & 2 \\
\hline
\end{tabular}




\section{Effect of $p H$}

The effect of $\mathrm{pH}$ was investigated in the $\mathrm{pH}$ range of 4.0-8.0 at $25^{\circ} \mathrm{C}$. The maximum activity of free enzyme was obtained at $\mathrm{pH} 6.0$ while for immobilized samples the optimum $\mathrm{pH}$ was taken to be 5.0 (Figure 5).

\section{Effect of Temperature}

The temperature effects on the activity of free and immobilized $\alpha$-amylase are shown in Figure 6. Free amylase had an optimum temperature of nearly $40^{\circ} \mathrm{C}$, while it shifted to $50^{\circ} \mathrm{C}$ for the immobilized system.

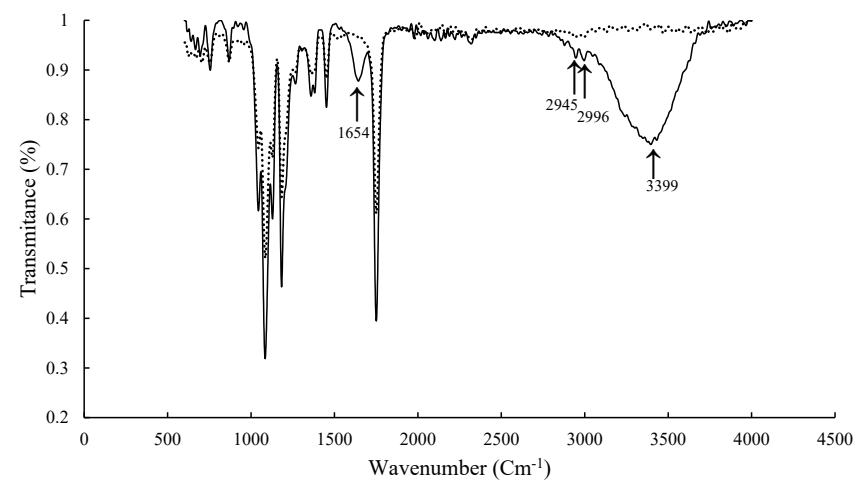

Figure 4. ATR-FTIR Spectrum of Plasma treated PES Nanofibers (...) and Enzyme-PES (-).

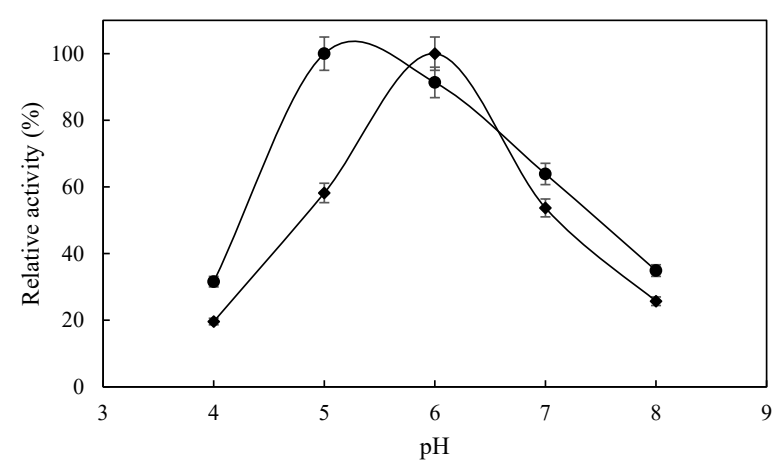

Figure 5. Effect of $\mathrm{pH}$ on Free $(\bullet)$ and Immobilized Enzyme $(\bullet)$ Activity

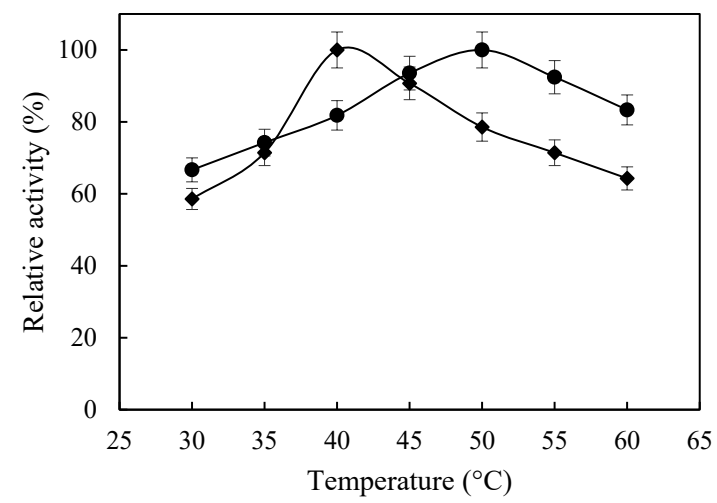

Figure 6. Effect of Temperature on Free $(\bullet)$ and Immobilized Enzyme $(\bullet)$ Activity

\section{Kinetic Parameters}

Double reciprocal plot (Lineweaver-Burk method) was used to determine the kinetics parameters, maximum reaction velocity $\left(V_{\max }\right)$ and Michaelis-Menten constant $\left(K_{m}\right)$, for the free and immobilized amylases as shown in Figure 7. In this study, $V_{\max }$ values were estimated as 0.15 and 0.16 units for free and immobilized enzymes, respectively, thus immobilization has no effect on the maximum velocity of the enzyme. $K_{m}$ values for free and immobilized enzymes were determined as 0.125 and $2.3 \mathrm{mg} / \mathrm{mL}$ respectively. The results show that immobilization causes approximately an 18 -fold increase in the $K_{m}$ values.

\section{Storage Stability}

Storage stability is one of the important advantages of immobilized enzymes over free enzymes. As shown in Figure 8 upon 9 days of storage, the catalytic activity of free and immobilized enzymes was retained $38 \%$ and $54 \%$ at experimental conditions, respectively.

\section{Repeated Use Capability}

The results showed that on repeated use of the immobilized $\alpha$-amylase up to 9 cycles within 9 days (Figure 9) the enzyme activity decreased to near zero.

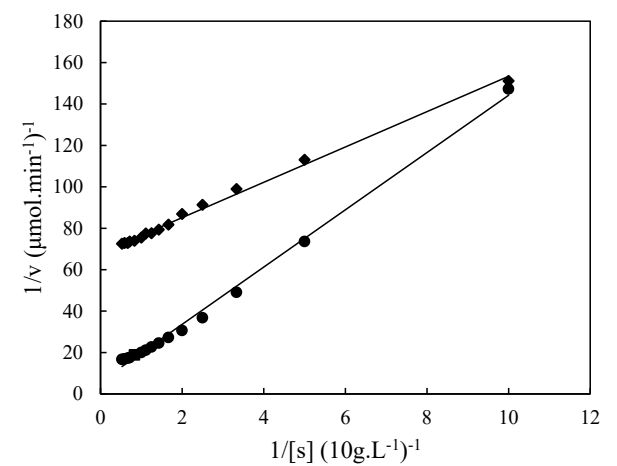

Figure 7. Lineweaver-Burk plots of free $(\bullet)$ and immobilized enzyme $(\bullet)$.

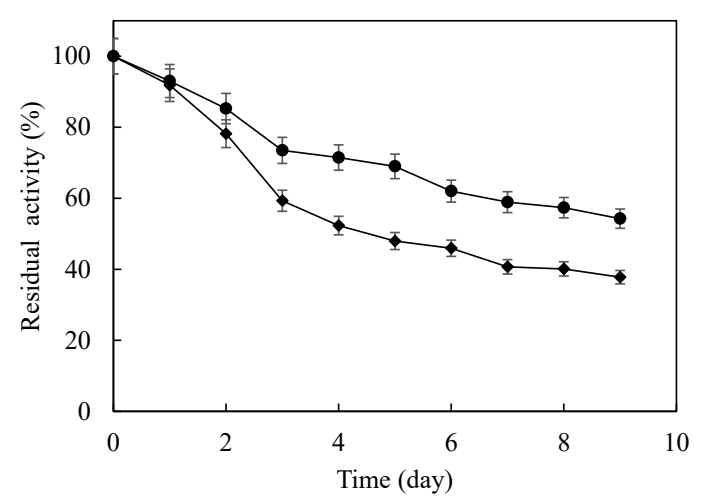

Figure 8. Storage Stability of Free $(\bullet)$ and Immobilized Enzyme $(\bullet)$ at $4{ }^{\circ} \mathrm{C}$ in Phosphate Buffer. 


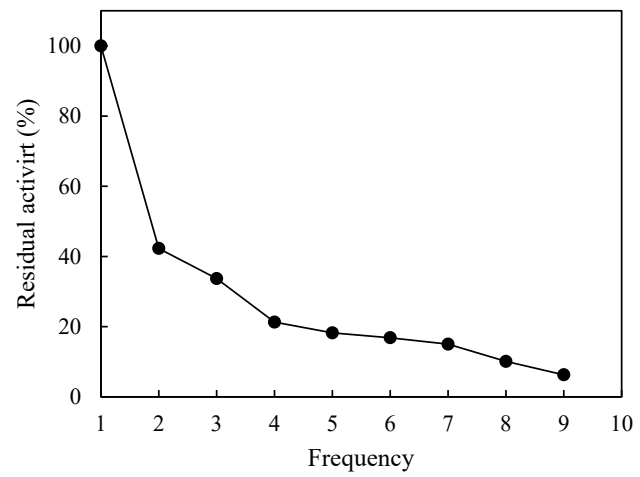

Figure 9. Frequency Use of Immobilized Enzyme at $50^{\circ} \mathrm{C}$ in Phosphate Buffer.

\section{Discussion}

Despite the great advantages of biocatalyst, their low stability in non-physiological or industrial conditions has led to the impossibility of usage of enzymes in long-term, repeated, and high-performance applications. The researchers' efforts to eliminate these constraints have resulted in some solutions such as modifying the enzyme or the reaction medium, protein engineering and enzyme immobilization..$^{23,24}$ It has been proven that covalent immobilization in many cases induces high resistance to temperature, denaturation and organic solvents. The extension of these enhancements may depend on other conditions of the system such as the nature of the enzyme, the type of substrate and the method of immobilization. The disadvantage often observed in covalent immobilization is the large stress placed on the enzyme that leads to significant changes in the enzyme conformation and consequently leads to loss of catalytic activity. ${ }^{25}$ Polymer materials are more suitable matrix for enzyme immobilization because they have some advantages such as presence of active agent groups, good mechanical characteristics, ease of preparation and combining with biocompatible materials to improve biocompatibility. ${ }^{26}$ Nanomaterials are considered for enzyme immobilization due to high surface-to-volume ratio. Nanoparticles, nanotubes, mesoporous silicon and nanofibers are the most widely used nanoscale materials in the immobilization of enzymes. ${ }^{27}$ The low cost of production, the ability to scale up and the variety of polymers are some advantages of electrospinning in comparison with other methods of nanofiber synthesis. ${ }^{28}$ PES is a polymer that has good features, including good mechanical properties, high thermal and chemical stability. It is also cheaper than the most of the other polymers, such as polybenzimidazole. ${ }^{29}$ This study was conducted to immobilize one of the most applicable industrial enzymes on solid and insoluble matrix in order to improve the biochemical parameters and enzyme conditions. Effective enzyme immobilization needs a hydrophil support. Oxygen plasma treatment provides the desired matrix by introducing many hydroxyl and carboxyl groups which, in general, enhance the hydrophilic properties of the nanofibers. The reduction of contact angle value generally means increased hydrophilicity which is an important factor in biomaterials. ${ }^{30}$ Optimization of enzyme immobilization conditions showed a bell shaped curve for $\mathrm{pH}$, EDC and enzyme concentrations.
It seems that increasing the amount of EDC from 20 to 60 $\mathrm{mM}$ caused more enzymes binding to the nanofiber and more activity. The further increase in the amount of added EDC caused steric hindrance and then reduction in the activity of the enzyme. ${ }^{31}$ Increasing the amount of the enzyme may have a similar effect so the best concentration of the enzyme for immobilization in this process is $2 \mathrm{mg} / \mathrm{mL}$. In order to confirm the immobilization of the enzyme in optimal conditions, the ATR-FTIR spectroscopy was performed. The formation of bond between carboxyl and amide groups resulted in a specific absorption peak, at about $1654 \mathrm{~cm}^{-1}$ indicating the presence of a given amount of amylase on electrospun nanofibrous matrix. The ATR-FTIR spectrum clearly marks the presence of bands related to N-H stretching (3200-3500 $\mathrm{cm}^{-1}$ ) and aromatic C-H stretching (2850-3500 $\mathrm{cm}^{-1}$ ) vibrations. ${ }^{32-34}$ The mentioned characteristic peaks, confirmed the immobilization of the enzyme on PES scaffold. In most cases, factors such as optimum $\mathrm{pH}$, temperature and kinetic parameters undergo some changes after enzyme immobilization. Partitioning effects of polyionic matrices play a critical role in dividing protons between the bulk phase and the enzyme microenvironment and causing a shift in the optimum $\mathrm{pH}$ value. ${ }^{35}$ The enzyme reaction, structure and charge of the matrix are some parameters that affect the $\mathrm{pH}$ shifting. ${ }^{36}$ The shift of $\mathrm{pH}$ value to the acidic or basic region upon immobilization is reported for amylase immobilization till now. ${ }^{37,38}$ In this study, the presence of positively charged groups on the matrix or some secondary interactions between the enzyme and the charged nanofibers may be caused a shift to acidic region. ${ }^{5}$ It seems that the creation of covalent bonds between the enzyme and the matrix causes conformational limitations on the enzyme movements, preventing protein denaturation and as a result, increasing the optimum temperature upon immobilization. ${ }^{39}$ Previous studies on a-amylase immobilization showed shifts towards both lower and higher temperatures. ${ }^{38,40,41} V_{\text {max }}$ is an innate property of an enzyme and the diffusional limitations affects this parameter. $K_{\mathrm{m}}$ depends upon both partitioning and diffusional effects. Some factors such as increased limitations of the substrate transfer or an interaction between the substrate and the support or the conformational changes of the enzyme can be caused higher $K_{m}$ value for immobilized enzyme. ${ }^{5,42}$ In this study, enhancement of storage stability of immobilized enzyme to free one, illustrates that the immobilization decreases denaturation. ${ }^{43}$ Singh et al reported storage stability of $65 \%$ and $83 \%$ for free and immobilized enzymes onto functionalized graphene nanosheets, respectively in 60 days. Also, in the reuse of the amylase enzyme after 10 times, 58\% of the initial activity remained. ${ }^{44}$ In another report, it was shown that the free amylase, lost all the activity during 15 days, but the immobilized enzyme on functionalized glass beads, lost only $20 \%$ of the activity in 25 days. ${ }^{34}$ Tuzmen et al reported that the free amylase lost all the activity within 35 days while the immobilized enzyme onto dye attached magnetic beads, lost $27 \%$ of its activity during the same days. ${ }^{26}$ Decreasing of enzyme activity upon repeated usage, may be due to enzyme unfolding and physical loss of enzyme from the matrices. ${ }^{3}$ 


\section{Conclusions}

PES nanofibers were prepared by electrospinning and modified via plasma treatment to improve hydrophilicity of scaffolds. Covalent binding of a-amylase enzyme to PES support was done using EDC activation process. Results indicate that the amylase immobilized on the PES nanofibers show improved optimum temperature and storage stability compared with free enzyme. Upon enzyme immobilization, the enzymes undergo changes in enzymatic activity and optimum $\mathrm{pH}$. The shift of optimum $\mathrm{pH}$ to acidic range for the immobilized alpha-amylase in comparison to the free enzyme and the maintenance of the maximum rate of the enzyme activity make this kind of nanofibrous scaffold-supported amylase applicable in starch industry.

\section{Author's Contributions}

Design and preformation of experiments, analyzing the data and writing the paper have been done by the author.

\section{Conflict of Interest Disclosures}

None to be declared.

\section{Acknowledgments}

Financial support from Research and Technology Council of Kharazmi University is gratefully acknowledged.

\section{References}

1. Singh S. A comparative study on immobilization of alpha amylase enzyme on different matricesIn. International Journal of Plant, Animal and Environmental Sciences. 2014;4(3):192-198.

2. Singh P, Gupta P, Singh R, Sharma R. Activity and stability of immobilized alpha-amylase produced by Bacillus acidocaldarius. Int J Pharm Life Sci. 2012;3(12 Suppl):2247-2253.

3. Raviyan P, Tang J, Rasco BA. Thermal stability of alpha-amylase from Aspergillus oryzae entrapped in polyacrylamide gel. J Agric Food Chem. 2003;51(18):5462-5466. doi:10.1021/jf020906j.

4. Guisan JM. Immobilization of Enzymes and Cells. In: Brena BM, Batista-Viera F, eds. New York: Humana Press; 2006:15-30.

5. Aksoy S, Tumturk H, Hasirci N. Stability of alpha-amylase immobilized on poly(methyl methacrylate-acrylic acid) microspheres. J Biotechnol. 1998;60(1-2):37-46.

6. Bryjak J. Glucoamylase, $\alpha$-amylase and $\beta$-amylase immobilisation on acrylic carriers. Biochem Eng J. 2003;16(3):347-355. doi:10.1016/S1369-703X(03)00114-1.

7. Guiavarc'h Y, Van Loey A, Zuber F, Hendrickx M. Bacillus licheniformis $\alpha$-amylase immobilized on glass beads and equilibrated at low moisture content: potentials as a TimeTemperature Integrator for sterilisation processes. Innov Food Sci Emerg Technol. 2004;5(3):317-325. doi:10.1016/j. ifset.2004.03.004.

8. Kara A, Osman B, Yavuz H, Besirli N, Denizli A. Immobilization of $\alpha$-amylase on $\mathrm{Cu} 2+$ chelated poly(ethylene glycol dimethacrylaten-vinyl imidazole) matrix via adsorption. React Funct Polym. 2005;62(1):61-68. doi:10.1016/j.reactfunctpolym.2004.08.008.

9. Konsoula Z, Liakopoulou-Kyriakides M. Starch hydrolysis by the action of an entrapped in alginate capsules $\alpha$-amylase from Bacillus subtilis. Process Biochem. 2006;41(2):343-349. doi:10.1016/j. procbio.2005.01.028.

10. Pandya PH, Jasra RV, Newalkar BL, Bhalt PN. Studies on the activity and stability of immobilized $\alpha$-amylase in ordered mesoporous silicas. Microporous Mesoporous Mater. 2005;77(1):67-77. doi:10.1016/j.micromeso.2004.08.018.

11. Mortazavi Milani Z, Jalal R, Goharshadi EK. Carbodiimide for Covalent a-Amylase Immobilization onto Magnetic Nanoparticles. Int J Nanosci. 2017; 16(5-6):1750015. doi:10.1142/ s0219581x17500156.

12. Ashly PC, Joseph MJ, Mohanan PV. Activity of diastase $\alpha$-amylase immobilized on polyanilines (PANIs). Food Chem. 2011;127(4):1808-1813. doi:10.1016/j.foodchem.2011.02.068.

13. Cordeiro AL, Lenk T, Werner C. Immobilization of Bacillus licheniformis alpha-amylase onto reactive polymer films. J Biotechnol. 2011;154(4):216-221. doi:10.1016/j. jbiotec.2011.04.008.

14. Dey G, Nagpal V, Banerjee R. Immobilization of alpha-amylase from Bacillus circulans GRS 313 on coconut fiber. Appl Biochem Biotechnol. 2002;102-103(1-6):303-313.

15. Kumari A, Kayastha AM. Immobilization of soybean (Glycine max) $\alpha$-amylase onto Chitosan and Amberlite MB-150 beads: Optimization and characterization. J Mol Catal B Enzym. 2011;69(1-2):8-14. doi:10.1016/j.molcatb.2010.12.003.

16. Namdeo $M$, Bajpai SK. Immobilization of $\alpha$-amylase onto cellulose-coated magnetite (CCM) nanoparticles and preliminary starch degradation study. J Mol Catal B Enzym. 2009;59(1-3):134139. doi:10.1016/j.molcatb.2009.02.005.

17. Soleimani M, Khani A, Najafzadeh K. $\alpha$-Amylase immobilization on the silica nanoparticles for cleaning performance towards starch soils in laundry detergents. J Mol Catal B Enzym. 2012;74(12):1-5. doi:10.1016/j.molcatb.2011.07.011.

18. Datta S, Christena LR, Rajaram YR. Enzyme immobilization: an overview on techniques and support materials. 3 Biotech. 2013;3(1):1-9. doi:10.1007/s13205-012-0071-7.

19. Basturk E, Demir S, Danıs O, Kahraman MV. Covalent immobilization of $\alpha$-amylase onto thermally crosslinked electrospun PVA/PAA nanofibrous hybrid membranes. J Appl Polym Sci. 2013;127(1):349-355. doi:10.1002/app.37901.

20. Oktay B, Demir S, Kayaman-Apohan N. Immobilization of alphaamylase onto poly(glycidyl methacrylate) grafted electrospun fibers by ATRP. Mater Sci Eng C Mater Biol Appl. 2015;50:386393. doi:10.1016/j.msec.2015.02.033.

21. Bernfeld P. Amylase $\alpha$ and $\beta$. In: Colowick SP, Kaplan NO, eds. Methods in Enzymology. New York: Academic Press Inc; 1955:149-158. Vol. 1. doi:10.1016/0076-6879(55)01021-5

22. Miller GL. Use of dinitrosalicylic acid reagent for the determination of reducing sugar. Anal Chem. 1959;31(3):426-428. doi:10.1021/ ac60147a030.

23. Dey TB, Kumar A, Banerjee R, Chandna P, Kuhad RC. Improvement of microbial $\alpha$-amylase stability: Strategic approaches. Process Biochem. 2016;51(10):1380-1390. doi:10.1016/j. procbio.2016.06.021.

24. Homaei A, Saberi D. Immobilization of $\alpha$-amylase on gold nanorods: An ideal system for starch processing. Process Biochem. 2015;50(9):1394-1399. doi:10.1016/j.procbio.2015.06.002.

25. Mohamad NR, Marzuki NH, Buang NA, Huyop F, Wahab RA. An overview of technologies for immobilization of enzymes and surface analysis techniques for immobilized enzymes. Biotechnol Biotechnol Equip. 2015;29(2):205-220. doi:10.1080/13102818.2 015.1008192.

26. Tuzmen N, Kalburcu T, Denizli A. $\alpha$-Amylase immobilization onto dye attached magnetic beads: Optimization and characterization. J Mol Catal B Enzym. 2012;78:16-23. doi:10.1016/j. molcatb.2012.01.017.

27. Gupta MN, Kaloti M, Kapoor M, Solanki K. Nanomaterials as matrices for enzyme immobilization. Artif Cells Blood Substit Immobil Biotechnol. 2011;39(2):98-109. doi:10.3109/10731199 .2010.516259.

28. Huang ZM, Zhang YZ, Kotaki M, Ramakrishna S. A review on polymer nanofibers by electrospinning and their applications in nanocomposites. Compos Sci Technol. 2003;63(15):2223-2253. doi:10.1016/S0266-3538(03)00178-7.

29. Alenazi NA, Hussein MA, Alamry KA, Asiri AM. Modified polyether-sulfone membrane: a mini review. Des Monomers Polym. 2017;20(1):532-546. doi:10.1080/15685551.2017.1398 208. 
30. Li Y, Quan J, Branford-White C, Williams GR, Wu JX, Zhu LM. Electrospun polyacrylonitrile-glycopolymer nanofibrous membranes for enzyme immobilization. J Mol Catal B Enzym. 2012;76:15-22. doi:10.1016/j.molcatb.2011.12.003.

31. Kazenwadel F, Wagner H, Rapp BE, Franzreb M. Optimization of enzyme immobilization on magnetic microparticles using 1-ethyl3-(3-dimethylaminopropyl)carbodiimide (EDC) as a crosslinking agent. Anal Methods. 2015;7(24):10291-10298. doi:10.1039/ C5AY02670A.

32. Ge L, Zhao YS, Mo T, Li JR, Li P. Immobilization of glucose oxidase in electrospun nanofibrous membranes for food preservation. Food Control. 2012;26(1):188-193. doi:10.1016/j. foodcont.2012.01.022.

33. Ghosh S, Chaganti SR, Prakasham RS. Polyaniline nanofiber as a novel immobilization matrix for the anti-leukemia enzyme I-asparaginase. J Mol Catal B Enzym. 2012;74(1-2):132-137. doi:10.1016/j.molcatb.2011.09.009

34. Kahraman MV, Bayramoglu G, Kayaman-Apohan N, Gungor A. $\alpha$-Amylase immobilization on functionalized glass beads by covalent attachment. Food Chem. 2007;104(4):1385-1392. doi:10.1016/j.foodchem.2007.01.054

35. Dwevedi A. Enzyme Immobilization: Advances in Industry, Agriculture, Medicine, and the Environment. Switzerland: Springer; 2016.

36. Bisswanger H. Enzyme assays. Perspect Sci. 2014;1(1-6):41-55. doi:10.1016/j.pisc.2014.02.005

37. Bayramoglu Z, Akbulut U, Sungur S. Immobilization of alphaamylase into photographic gelatin by chemical cross-linking. Biomaterials. 1992;13(10):704-708.
38. Arica MY, Hasirci V, Alaeddinoglu NG. Covalent immobilization of alpha-amylase onto pHEMA microspheres: preparation and application to fixed bed reactor. Biomaterials. 1995;16(10):761768.

39. Wang ZG, Ke BB, Xu ZK. Covalent immobilization of redox enzyme on electrospun nonwoven poly(acrylonitrile-coacrylic acid) nanofiber mesh filled with carbon nanotubes: a comprehensive study. Biotechnol Bioeng. 2007;97(4):708-720. doi:10.1002/bit.21280.

40. Lee PM, Lee KH, Siaw YS. Covalent immobilization of aminoacylase to alginate for L-phenylalanine production. J Chem Technol Biotechnol. 1993;58(1):65-70. doi:10.1002/jctb.280580109.

41. Demircioglu H, Beyenal $\mathrm{H}$, Tanyolac A, Hasirci N. Immobilization of urease and estimation of effective diffusion coefficients of urea in HEMA and VP copolymer matrices. Polym Int. 1994;35(4):321327. doi:10.1002/pi.1994.210350404.

42. El-Aassar MR, Al-Deyab SS, Kenawy ER. Covalent immobilization of $\beta$-galactosidase onto electrospun nanofibers of poly (AN-COMMA) copolymer. J Appl Polym Sci. 2013;127(3):1873-1884. doi:10.1002/app.37922.

43. El-Aassar MR. Functionalized electrospun nanofibers from poly (AN-co-MMA) for enzyme immobilization. J Mol Catal B Enzym. 2013;85-86:140-148. doi:10.1016/j.molcatb.2012.09.002.

44. Singh K, Srivastava G, Talat M, Srivastava ON, Kayastha AM $\alpha$-Amylase immobilization onto functionalized graphene nanosheets as scaffolds: Its characterization, kinetics and potential applications in starch based industries. Biochem Biophys Rep. 2015;3:18-25. doi:10.1016/j.bbrep.2015.07.002. 